\title{
A review of the surgical options for the correction of presbyopia
}

\author{
Raquel Gil-Cazorla, ${ }^{1,2}$ Sunil Shah, ${ }^{1,2,3}$ Shehzad A Naroo ${ }^{1}$
}

\begin{abstract}
1 Ophthalmic Research Group, School of Life and Health Sciences, Aston University, Birmingham, UK

${ }^{2}$ Midland Eye, Solihull, UK ${ }^{3}$ Birmingham and Midland Eye Centre, City Hospital, Birmingham, UK
\end{abstract}

\section{Correspondence to} Dr Shehzad A Naroo, Ophthalmic Research Group, Aston University, Aston Street, Birmingham, West Midlands B4 7ET, UK;

s.a.naroo@aston.ac.uk

Received 20 January 2015 Revised 30 March 2015 Accepted 4 April 2015 Published Online First 23 April 2015

\section{ABSTRACT}

Presbyopia is an age-related eye condition where one of the signs is the reduction in the amplitude of accommodation, resulting in the loss of ability to change the eye's focus from far to near. It is the most common age-related ailments affecting everyone around their mid40 s. Methods for the correction of presbyopia include contact lens and spectacle options but the surgical correction of presbyopia still remains a significant challenge for refractive surgeons. Surgical strategies for dealing with presbyopia may be extraocular (corneal or scleral) or intraocular (removal and replacement of the crystalline lens or some type of treatment on the crystalline lens itself). There are however a number of limitations and considerations that have limited the widespread acceptance of surgical correction of presbyopia. Each surgical strategy presents its own unique set of advantages and disadvantages. For example, lens removal and replacement with an intraocular lens may not be preferable in a young patient with presbyopia without a refractive error. Similarly treatment on the crystalline lens may not be a suitable choice for a patient with early signs of cataract. This article is a review of the options available and those that are in development stages and are likely to be available in the near future for the surgical correction of presbyopia.

\section{INTRODUCTION}

Presbyopia is an age-related reduction in the amplitude of accommodation and leads to the loss of ability in changing the eyes' focus between far and near. The correction of presbyopia without resorting to spectacles and contact lenses (CLs) remains the Holy Grail for refractive surgeons as well as the billions of patients with presbyopia.

Numerous accommodative and pseudoaccommodative approaches to treat presbyopia surgically exist. Each has its own benefits and limitations, and may involve some degree of compromise between the distance and near visual acuities (VA). Accommodative approaches attempt to restore the true, dynamic and continuous range of the defocusing ability of the eye. Pseudoaccommodative approaches provide functional near vision from a variety of non-accommodative factors.

This review provides an overview of the options that are currently available for the surgical management of presbyopia.

\section{PSEUDOACCOMMODATIVE APPROACHES Corneal approaches}

Excimer laser procedures Monovision

Monovision with an excimer laser is a wellestablished technique that corrects one eye for distance vision (usually dominant eye) and the other eye for near vision, resulting in intentional anisometropia. ${ }^{1}$ This aim is to give functional near and distant VAs without the need for glasses. The mechanism that enables monovision to succeed is interocular blur suppression.

Studies have reported success rates ranging from $80-98 \%{ }^{1-5}$ for monovision post laser vision correction (LVC), 91\% for monovision after cataract surgery and 95\% following clear lens extraction ${ }^{6}$ with good satisfaction. Surgically induced monovision is associated with a higher success rate than with CLs (91-98\%), but it is unclear whether this is because it is harder to reverse the procedure or because of a multifocal corneal shape in LVC.

Limitations of monovision include compromising visual function, such as reduced low contrast VA and contrast sensitivity (CS), inability to incorporate an intermediate vision correction without compromising distance vision or near vision, reduced stereopsis, and small-angle esotropic shift. ${ }^{2}$ 7-9

\section{Multifocal corneal ablation}

Multifocality achieved by excimer ablation sometimes known as presbyLasik, is interesting to refractive surgeons because it is familiar, seems less invasive than intraocular surgery and could theoretically be more controllable. However, this is against the conventional thinking for LVC where one usually attempts to minimise the higher order aberrations.

A variety of presbyopic LVC procedures exist. ${ }^{10-12}$ In peripheral prebyopic LVC, the peripheral cornea is ablated to create negative peripheral asphericity. Thus the central cornea is for distance vision and the mid-peripheral cornea for near vision (eg, Nidek Advanced Vision Excimer Laser; (NIDEK, Gamagori, Japan). ${ }^{11}$ In central presbyopic LVC, the central area is ablated for near vision and the periphery for distance vision (eg, Supracor, Technolas Perfect Vision GmbH, München, Germany); and Pulsar (CustomVis, CV Laser, Perth, Australia).

Although optically the results are predictable and good, some patients find it difficult to adapt to the compromise and others are dissatisfied by the minor loss of distance VA. ${ }^{12} 13$

Presbyond Laser Blended Vision (Carl Zeiss Meditec, Jena, Germany) is an optimised laser treatment method attempting to improve on conventional monovision. The dominant eye is treated for distance vision to almost plano and the nondominant eye is corrected to be slightly myopic for near vision to $-1.5 \mathrm{D}$. This monovision treatment is enhanced by the use of a wavefront-optimised ablation profile to create a continuous refractive power gradient for the whole optical zone of the 
cornea. Studies show that this treatment is a well-tolerated and effective procedure for treating patients with presbyopia. ${ }^{14-16}$

More recently, SCHWIND eye-tech-solutions (Kleinostheim, Germany) introduced its PresbyMAX software. This is a biaspherical cornea modulation technique, based on the creation of a central hyperpositive area for near vision and leaving the pericentral cornea for far vision. Uthoff $e t a l^{17}$ reported good distance and near visual outcomes in a 6-month follow-up study (table 1).

While multifocal LVCs represent a promising avenue for future presbyopic correction, outcome data is relatively sparse compared with other modalities. ${ }^{74}$

\section{Conductive keratoplasty}

Conductive keratoplasty (CK) is the successor of laser thermokeratoplasty. CK uses the application of low frequency radio waves to 'shrink' collagen fibrils within the mid-peripheral cornea. This causes a net steepening on the central cornea and thus increases the positive power of the eye. Radiofrequency energy is typically $0.6 \mathrm{~W}$ with a 0.6 -s treatment time, ${ }^{25}$ delivered through a fine tip inserted into the peripheral corneal stroma in a ring pattern outside of the visual axis. Eight to 32 treatment spots are placed in up to three rings in the corneal periphery $(6-\mathrm{mm}, 7-\mathrm{mm}$ and $8-\mathrm{mm}$ optical zones) and striae form between the spots and create a band of tightening to steepen the cornea primarily to create monovision. Although this has shown to be a relatively safe technique and may present theoretical advantages over flap creation techniques (less invasive and no flap-related complications), long-term studies report high rate of regression and hence this is not a popular technique at present. ${ }^{18} 26-28$

\section{Intrastromal femtosecond ring incisions}

Although the primary application of femtosecond laser has been its use in the creation of Laser-Assisted in situ Keratomileusis (LASIK) flaps, its precision and safety features makes it a useful tool for many types of corneal refractive surgery, including intrastromal treatments. Typically, five concentric rings in the cornea stroma between $2 \mathrm{~mm}$ and $4 \mathrm{~mm}$ from the line of sight are created using a femtosecond laser. Studies with INTRACOR (Technolas Perfect Vision GmbH, München, Germany) have shown the technique to be efficient and safe. ${ }^{29} 30$

The main advantage of INTRACOR is that the corneal surface is not cut. The ring structure induces a localised biomechanical change in the tissue causing a slight central steepening of 1-2 dioptres (D). This steepening changes the spherical aberration (SA) and corneal asphericity, resulting in improvement in the near vision. ${ }^{29-32}$ To date, the results reported have shown an overall improvement of uncorrected near VA (UCNVA). ${ }^{19}$ 29-32 However, some studies report no improvement in UCNVA at 1 month, ${ }^{19}{ }^{30}$ reduced best distance corrected VA (BDCVA), ${ }^{19} 31$ and anterior corneal protrusion after hyperopic LASIK followed by INTRACOR. ${ }^{33}$ The treatment is usually performed in the non-dominant eye only. Further study is required on this treatment modality.

\section{Corneal inlays}

Corneal inlays (CIs) are intrastromal implants which are placed underneath a LASIK flap or into a femtosecond laser created corneal pocket. The pocket technique has a number of potential advantages: the majority of peripheral corneal nerves are preserved, allowing corneal sensitivity to be maintained, they are additive, do not remove tissue, preserve future options for presbyopic correction and may be used in pseudophakia and/or combined with LVC. ${ }^{34}$ In addition, they are all removable. The LASIK flap could be created with a microkeratome or with a femtosecond laser.

Complications reported with CI include hyperopic shift, haloes, a decrease in photopic and mesopic CS, corneal thinning and melting, broadened defocus curve and reduced simulated retinal blur in the implanted eye (Kamra Inlay, AcuFocus, Irvine, California, USA). ${ }^{22}{ }^{35-37}$ With all inlay designs, centration is critical for proper performance, and a small displacement can make a clinically significant difference. ${ }^{38}$

At present, there are three types of corneal inlays:

- CIs that alter the index of refraction with a bifocal optic. The Flexivue Microlens, (Presbia, Los Angeles, California, USA) and Icolens (Neoptics AG, Hunenberg, Switzerland) are currently in clinical trials although several studies have been presented. The Flexivue (precursor was the Invue) is the only CI using a refractive addition power. ${ }^{20}$

The Icolens is a new CI and recently Baily has reported the 1-year visual outcomes (table 1 ). ${ }^{23}$

- The Raindrop Near Vision Inlay (ReVision Optics, Lake Forest, California, USA) is a CI that changes the corneal curvature. Garza $e a^{21}$ reported good and stable results at 1 year.

- The Kamra CI relies on small-aperture optics to increase the depth of focus. Most of the published data demonstrates that monocular implantation of a small-aperture inlay results in sustained improvement in near vision and intermediate vision while maintaining good distance vision. ${ }^{22}$ 35-37 However, the size, material and visibility of the Kamra CI can be a disadvantage compared with the other CIs.

\section{Lenticular approaches}

The ultimate goal of cataract extraction and clear lens extraction is to replace the crystalline lens with an intraocular lens (IOL) that simulates the original function of the crystalline lens and provides the patients with a full range of functional vision for all distances. Currently, the available IOLs can be grouped into accommodating (AIOLs) or pseudoaccommodating IOLs (although the mechanism of action of some 'accommodative lenses' may be pseudoaccommodative in nature). With pseudoaccommodative multifocal IOLs (MIOLs), the patient has two or three points in focus but primarily perceives only the focused image of interest. ${ }^{39} 40$

Precise biometry, accurate IOL power calculation, good surgical technique as well as patient selection are crucial in achieving the best visual outcome and patient satisfaction.

\section{Pseudophakic multifocal intraocular lens}

Multifocal intraocular lenses are used following patients with cataract or in clear lens extraction ${ }^{41}$ and excellent clinical outcomes have been reported. ${ }^{42}{ }^{43}$ However, patient dissatisfaction and secondary procedures, including IOL exchange, can also be significant. ${ }^{44}{ }^{45}$ Some of the MIOLs are based on multifocal CL designs, however the visual results may defer between them. First, CLs and IOLs are placed in different locations in the eye which results in different plane corrections, and second, the CL moves during the blink versus the stability of the IOL. These differences could lead to different visual outcomes.

Complications of theses MIOLs include reduction in quality of vision, especially loss of CS, dysphotopsia, and reduced intermediate vision and near vision. ${ }^{46}$

The discussion below is not an exhaustive list of the IOLs available or publications (it is beyond the scope of this article) but is representative for the common lenses used. 
Table 1 Visual outcomes of presbyopia procedures

\begin{tabular}{|c|c|c|c|c|c|c|c|}
\hline Author & Procedure & Study design & Number of eyes & UCNVA & BDCNVA & Additional tests & Complications \\
\hline Levinger et $a l^{4}$ & $\begin{array}{l}\text { Monovision } \\
\text { induced by LASIK }\end{array}$ & 1 year & 38 & 0.06 logMAR (binocular & Not available & $\begin{array}{l}\text { CS reduced in mesopic } \\
\text { condition. } \\
\text { Near stereoacuity } 57 \mathrm{~s} \text { of arc } \\
\text { 85.2\% of satisfaction }\end{array}$ & Not reported \\
\hline Greenbaum $^{6}$ & $\begin{array}{l}\text { Monovision } \\
\text { pseudophakia }\end{array}$ & 1 year & 120 cataract/20 CLE & $\begin{array}{l}0.0 \text { logMAR or better (binocular) in } \\
91 \% \text { cataract and } 95 \% \text { CLE }\end{array}$ & Not available & $\begin{array}{l}\text { - } 91 \% \text { acceptance cataract } \\
\text { - } 95 \% \text { acceptance CLE }\end{array}$ & $\begin{array}{l}\text { } 1 \text { dry eye } \\
\text { } 1 \text { vitreous loss } \\
\text { } 1 \text { iris atrophy } \\
\text { 2 } 20 \% \text { reported haloes and } \\
\text { glare in cataract in CLE }\end{array}$ \\
\hline Uthoff et al $\left.\right|^{17}$ & $\begin{array}{l}\text { Multifocal corneal } \\
\text { ablation }\end{array}$ & 6 months & $\begin{array}{l}20 \text { (emmetropic), } 20 \\
\text { (hyperopic), } 20 \text { (myopic) }\end{array}$ & $\begin{array}{l}0.18 \text { logRAD (emmetropic), } 0.24 \\
\text { logRAD (hyperopic), } 0.12 \text { logRAD } \\
\text { (myopic) binocular }\end{array}$ & Not available & $\begin{array}{l}\text { CS significantly reduced in all } \\
\text { groups }\end{array}$ & Not reported \\
\hline McDonald et $a l^{18}$ & $\begin{array}{l}\text { Conductive } \\
\text { keratoplasty }\end{array}$ & 6 months & 143 & $\begin{array}{l}0.18 \text { logMAR or better in } 77 \% \\
\text { (monocular) }\end{array}$ & Not available & $\begin{array}{l}76 \% \text { reported very satisfied/ } \\
\text { satisfied }\end{array}$ & Not reported \\
\hline Menassa et $a l^{19}$ & $\begin{array}{l}\text { Intrastromal } \\
\text { femtosecond Ring } \\
\text { incision }\end{array}$ & 18 months & 25 & $0.2 \log M A R$ (monocular) & Not available & Corneal steepening $0.90 \mathrm{D}$ & $\begin{array}{l}\text { - } 36 \% \text { reported rings around } \\
\text { light sources }\end{array}$ \\
\hline Limnopoulou et a $\left.\right|^{20}$ & $\begin{array}{l}\text { Flexivue microlens } \\
\text { inlay }\end{array}$ & 1 year & 47 & $\begin{array}{l}0.14 \text { logMAR (monocular), } 0.13 \\
\text { logMAR (binocular) }\end{array}$ & Not available & $\begin{array}{l}\text { HOA increased. } \\
\text { CS decreased. } \\
\text { } 81.25 \% \text { reported } \\
\text { UCNVA excellent }\end{array}$ & No surgical complications \\
\hline Garza et $\left.a\right|^{21}$ & The raindrop Inlay & 1 year & 20 & $\begin{array}{l}<0.1 \log \text { MAR (monocular and } \\
\text { binocular) }\end{array}$ & Not available & $\begin{array}{l}\text { Photopic CS no significant } \\
\text { change. } \\
\text { 95\% reported satisfied or very } \\
\text { satisfied UCNVA, UCIVA. } \\
\text { 100\% satisfied or very satisfied } \\
\text { UCDVA }\end{array}$ & $\begin{array}{l}\text { - } 1 \text { patient reported severe } \\
\text { haloes at } 6 \text { months, } \\
10 \% \text { inlays removed } \\
\text { because dissatisfaction, } \\
\text { decentration. }\end{array}$ \\
\hline Seyeddain et $a l^{22}$ & The Kamra inlay & 2 years prospective & 24 & 0.1 logMAR (monocular) & Not available & 0.1 logMAR UCIVA & $\begin{array}{l}\text { } 1 \text { eye with epithelial } \\
\text { ingrowth in the pocket } \\
\text { 1eye with epithelial iron } \\
\text { deposit }\end{array}$ \\
\hline Baily et $a l^{23}$ & $\begin{array}{l}\text { The Icolens corneal } \\
\text { inlay }\end{array}$ & 1 year & 52 & $0.4 \log \mathrm{MAR}$ (monocular) & Not available & $\begin{array}{l}90 \% \text { reported happy with the } \\
\text { procedure }\end{array}$ & $\begin{array}{l}11 \text { inlay explanted because } \\
\text { minimal improvement UCNVA }\end{array}$ \\
\hline $\begin{array}{l}\text { Hipsley } \\
\text { (ASCRS 2011) }\end{array}$ & $\begin{array}{l}\text { The LaserACE } \\
\text { procedure }\end{array}$ & 18 months & 134 & $0.18 \log M A R$ or better in $89 \%$ & Not available & $\begin{array}{l}1.25-1.75 \mathrm{D} \text { increase in } \\
\text { objective accommodation. } \\
0.18 \text { logMAR or better in } 95 \% \\
\text { UCIVA }\end{array}$ & No major complications \\
\hline Berrow $(2014)^{62}$ & $\begin{array}{l}\text { PresVIEW scleral } \\
\text { implant }\end{array}$ & $\begin{array}{l}3 \text { months (ongoing } \\
2 \text { years FDA clinical } \\
\text { trial) }\end{array}$ & 28 & Not available & $\begin{array}{l}0.3 \text { logMAR } 100 \% \\
\text { (monocular, binocular) }\end{array}$ & $\begin{array}{l}\text { Mean lines of improvement at } \\
\text { near } 2.3 \text { monocular and } 2.0 \\
\text { binocular }\end{array}$ & Not reported \\
\hline
\end{tabular}

Note: some visual acuities were converted to logMAR using the visual acuity conversion chart prepared by Jack T Holland.

BDCNVA, best distance corrected near visual acuity; CLE, clear lens extraction; CS, contrast sensitivity; FDA, Food and Drug Administration; HOA, high order aberration; LogMAR, log minimum angle of resolution; logRAD, logarithm of the reading acuity determination; UCDVA, uncorrected distance visual acuity; UCIVA, uncorrected intermediate visual acuity; UCNVA, uncorrected near visual acuity. 


\section{Refractive MIOLs}

Refractive MIOLs have the incorporation of two different powers integrated into two or more typically circular refractive zones. Due to each lens zone having a different effective aperture, the image quality can depend on the pupillary response to light and the accommodation reflex. ${ }^{47}$

The ReZoom (Abbot Medical Optics (AMO), Irvine, California, USA) is a refractive MIOL (the original model being called the ARRAY) and the Food and Drug Administration (FDA) approved it in 2005. It is a three-piece MIOL and has five refractive optical zones; zones 1,3 and 5 are adjusted for far vision, while zones 2 and 4 are adjusted for near vision. This design gives good distance vision and good intermediate-range vision although the reading performance is variable. ${ }^{48}$ Disadvantages of this lens, like many MIOLs, include dysphotopsia. ${ }^{49}$

The M-flex MIOL (Rayner IOLs Limited, Hove, UK) is based on a multizoned refractive aspherical optical technology, with either 4 or 5 annular zones (depending on IOL base power) providing $+3.0 \mathrm{D}$ or $+4.0 \mathrm{D}$ of additional refractive power at the IOL plane (equivalent to $+2.25 \mathrm{D}$ or $+3.0 \mathrm{D}$ at the spectacle plane). Cezon et $a l^{50}$ reported good visual performance and high rate of spectacle independence at 1 year.

Refractive MIOLs appear to be associated with more photic phenomena compared with diffractive MIOLs. ${ }^{51}$ Photic phenomena are among the most frequent reasons for patient dissatisfaction following implantation of MIOLs. ${ }^{44} 52$

\section{Diffractive MIOLS}

These are based on the principle of diffraction, whereby light slows down and changes direction when it encounters an obstacle. ${ }^{53}$ These lenses use microscopic steps (diffractive zones) across the lens surface. As light encounters these steps, it is directed towards the distant and near focal points (the amount of light is directly related to the step height as a proportion of wavelength). Diffractive MIOLs can be subdivided into apodised (gradual reduction in diffractive step heights from centre to periphery) or non-apodised (uniform height): both categories are designed to reduce the severity of night haloes compared with refractive MIOLs. ${ }^{47}$ Examples include the ReSTOR (Alcon Lab, Fort Worth, Texas, USA) (apodised) and Tecnis Multifocal (Abbott Medical Optics, Santa Ana, California, USA) and AT LISA 809 IOL (Carl Zeiss Meditec, Hennigsdorf, Germany) (both non-apodised). Most studies report good and stable distance vision and near vision, leading to low spectacle dependence and high patient satisfaction. ${ }^{54-56}$ Although these designs have good visual outcomes, their weakest points can be their inability to provide good levels of vision at an intermediate distance and loss of CS.

Aiming to improve intermediate vision, trifocal MIOL designs were introduced in the market: AT Lisa tri 839MP novel design (Carl Zeiss Meditec, Hennigsdorf, Germany), FineVision (PhysIOL SA, Liège, Belgium) and MIOL-Record trifocal IOL (Reper NN, Nizhny Novgorod, Russia). Results reported so far of theses lenses show a significant improvement in uncorrected VA at all distances. The trifocal designs may be the emerging technology in the field of the diffractive IOLs. ${ }^{57} 58$ The prevalence of complications still needs to be assessed with larger clinical studies.

\section{Rotationally asymmetrical MIOLs}

All traditional MIOLs are based on the concept of rotational symmetry. Recently, MIOLs with rotational asymmetry were introduced. One such lens, the Lentis MPlus LS-312 (Oculentis
$\mathrm{GmbH}$, Berlin, Germany), consists of a single-piece, aspherical surface that is independent of pupil size. ${ }^{59}$ Different near additions are available allowing customisations for each individual and can be used with a mix and match philosophy.

Results indicate good distance, intermediate and near VAs with a high level of CS. ${ }^{59-61}$ The authors recently conducted a study with the latest version: Lentis Mplus X LS-313 in 34 eyes showing excellent visual performance ${ }^{62}$ (table 2).

The SBL-3 MIOL (Lenstec, St Petersburg, Florida, USA) is another asymmetrical segmented MIOL that is also designed to improve CS, minimise dysphotopsias and provide good far vision, intermediate vision and near vision. The SBL-3 has a three-dimensional sector-shaped near vision addition with a seamless transition zone between the distance and near segments. Venter et $a l^{63}$ recently published a study conducted in 106 eyes showing excellent outcomes (table 2).

Rotationally asymmetrical MIOLs seem to provide a good visual outcome at distance vision and near vision with minimal dysphotopsia and retain intermediate vision. The design minimises loss of light from splitting of the incoming light. Patients also were satisfied with their uncorrected near vision. Further studies with larger cohorts and longer follow-up period are necessary.

Finally, Staar (Staar Surgical Company, Monrovia, California) is known to be developing a new multifocal phakic implantable contact lens that would potentially correct ametropia and presbyopia.

\section{Phakic MIOL}

Ametropia and presbyopia can also be corrected using an anterior chamber phakic MIOL. George Baikoff designed one of the first models ${ }^{6469}$ and this anterior chamber multifocal design has been marketed under the trade names of Newlife (IOLTECH, SA, La Rochelle, France) and Vivarte Presbyopic (CibaVision, Duluth, Georgia, USA) and provides a single addition of $+2.5 \mathrm{D}$ for near vision.

Baikoff $e t a l^{64}$ also performed the first clinical trial with this type of multifocal IOL in 55 eyes showing that this IOL was effective and gave good predictability. Alio and Mulet, in another pilot study with a multifocal phakic IOL prototype (AMO, Irvine, California, USA), also showed good results. ${ }^{65}$ However, the complications reported by these anterior phakic IOLs include endophthalmitis, surgically induced astigmatism, corneal endothelial cell loss, pupil distortion, chronic uveitis, pupillary block glaucoma, pigment dispersion syndrome and cataracts.

\section{ACCOMMODATIVE APPROACHES}

For accommodation to be restored in the presbyopic eye, it is necessary that the ciliary muscle is still able to contract with accommodative effort: there is evidence to suggest that the ciliary muscle does not undergo atrophy with age and remains functional. ${ }^{70}$ Although the young phakic eye may have $7-8 \mathrm{D}$ of true accommodation, most patients with presbyopia would be happy with a restoration of 2-3 D of true accommodation.

\section{Lenticular approaches}

\section{Accommodating intraocular lens}

There are many different concepts and designs for AIOLs including mouldable gels, fluid displacement and flexible haptics. These IOLs are designed to use ciliary muscle contraction, capsular bag elasticity and changes in vitreous cavity pressure to induce change or movement in the shape of the IOL to produce an optical change in the eye based on the optic-shift concept, that is, on the 
Table 2 Visual results of intraocular lenses (IOLs)

\begin{tabular}{|c|c|c|c|c|c|c|c|c|}
\hline Author & IOL & Design & $\begin{array}{l}\text { Study } \\
\text { design }\end{array}$ & $\begin{array}{l}\text { Number } \\
\text { of eyes }\end{array}$ & UCNVA & BDCNVA & Additional tests & Complications \\
\hline Forte and Ursoleo ${ }^{48}$ & ReZoom & Refractive & 2 years & 55 & $\begin{array}{l}0.10 \text { logMAR } \\
\text { (monocular) }\end{array}$ & Not available & $\begin{array}{l}\text { UCIVA } 0.07 \text { logMAR (monocular). } \\
7 \% \text { patients reported moderate } \\
\text { glare } \\
5 \% \text { patients reported moderate } \\
\text { halo }\end{array}$ & Not reported \\
\hline Cezon et al ${ }^{50}$ & Rayner M-flex & Refractive & 1 year & 32 & $\begin{array}{l}0.28 \text { logMAR } \\
\text { (monocular) }\end{array}$ & $\begin{array}{l}0.28 \text { logMAR } \\
\text { (monocular) }\end{array}$ & $\begin{array}{l}\text { UCIVA } 0.15 \text { logMAR } \\
\text { CIVA } 0.15 \text { logMAR (monocular). }\end{array}$ & Not reported \\
\hline Kohnen et $\left.a\right|^{54}$ & $\begin{array}{l}\text { AcrySof ReSTOR } \\
\text { MA60D3 }\end{array}$ & Diffractive & 6 months & 127 & $\begin{array}{l}0.14 \log \text { MAR in } \\
66.9 \% \text { (binocular) }\end{array}$ & $\begin{array}{l}0.14 \text { logMAR in } \\
71.2 \% \text { (binocular) }\end{array}$ & $\begin{array}{l}\text { } 84.6 \% \text { spectacle independence for } \\
\text { near vision } \\
\text { 8.5\% patients reported severe } \\
\text { glare } \\
4.2 \% \text { patients reported severe } \\
\text { halo }\end{array}$ & $\begin{array}{l}\text { - } 2 \text { eyes implant replacements } \\
\text { - } 2 \text { eyes with cystoid macular } \\
\text { oedema } \\
\text { - } 1 \text { eye flat macular oedema } \\
\text { } 1 \text { eye macular oedema with } \\
\text { fibrous reaction } \\
\text { - } 1 \text { cystic maculopathy }\end{array}$ \\
\hline Packer et $a l^{55}$ & Tecnis multifocal & Diffractive & 1 year & 244 & $\begin{array}{l}0.20 \text { logMAR } \\
\text { (monocular) } \\
0.10 \text { logMAR } \\
\text { (binocular) }\end{array}$ & $\begin{array}{l}0.18 \text { logMAR } \\
\text { (monocular) } \\
0.10 \text { logMAR } \\
\text { (binocular) }\end{array}$ & $\begin{array}{l}\text { } 95.5 \% \text { spectacle independency for } \\
\text { distance vision } \\
\text { } 86.6 \% \text { spectacle independency for } \\
\text { near vision } \\
\text { } 94.6 \% \text { satisfied } \\
\text { } 10.3 \% \text { patients reported moderate } \\
\text { glare } \\
\text { } 2.6 \% \text { patients reported severe } \\
\text { glare } \\
\text { - } 84.8 \% \text { spectacle independence }\end{array}$ & $\begin{array}{l}\text { } 1 \text { pupilloplasty } \\
4 \mathrm{IOL} \text { explantation } \\
\text { laser }\end{array}$ \\
\hline Mojzis et $a^{57}$ & AT Lisa tri 839MP & Diffractive trifocal & 6 months & 60 & $\begin{array}{l}0.20 \text { logMAR } \\
\text { (monocular) }\end{array}$ & $\begin{array}{l}0.17 \text { logMAR } \\
\text { (monocular) }\end{array}$ & $\begin{array}{l}\text { - UCIVA } 0.08 \text { logMAR } \\
\text { DCIVA } 0.08 \text { logMAR (monocular) }\end{array}$ & Not surgical complications \\
\hline Sheppard et $a^{58}$ & Finevision trifocal & Diffractive trifocal & 2 months & 30 & Not available & Not available & $\begin{array}{l}\text { UCDVA } 0.19 \text { logMAR (monocular) } \\
\text { NAVQ Rasch scores satisfaction at } \\
\text { near } 15.9 \text { logits }\end{array}$ & Not reported \\
\hline Voskresenskaya et al ${ }^{56}$ & MIOL-Record trifocal & Diffractive trifocal & 6 months & 36 & $\begin{array}{l}0.10 \text { logMAR } \\
\text { (monocular) }\end{array}$ & $\begin{array}{l}0.10 \text { logMAR } \\
\text { (monocular) }\end{array}$ & $\begin{array}{l}\text { UCIVA, DCIVA } 0.2 \text { logMAR, } \\
\text { Scotopic } \\
\text { CS } 0.2 \text { log unit below standard } \\
\text { values at all spatial frequencies } \\
\text { - } 94 \% \text { patients reported spectacle } \\
\text { freedom } \\
\text { - } 25 \% \text { patients reported haloes }\end{array}$ & Not surgical complications \\
\hline Shah (2014) & Lentis Mplus X LS-313 & $\begin{array}{l}\text { Rotationally } \\
\text { asymmetrical }\end{array}$ & 3 months & 34 & $\begin{array}{l}0.18 \text { logMAR } \\
\text { (monocular) }\end{array}$ & $\begin{array}{l}0.15 \text { logMAR } \\
\text { (monocular) }\end{array}$ & $\begin{array}{l}\text { NAVQ Rasch scores satisfaction at } \\
\text { near } 20.43 \text { logits }\end{array}$ & Not surgical complications \\
\hline Venter et $a^{/ 63}$ & SBL-3 & $\begin{array}{l}\text { Rotationally } \\
\text { asymmetrical }\end{array}$ & 3 months & 106 & $\begin{array}{l}0.12 \text { logMAR } \\
\text { (monocular); } \\
\quad 0.08 \text { logMAR } \\
\text { (binocular) }\end{array}$ & $\begin{array}{l}0.11 \text { logMAR } \\
\text { (monocular); } \\
\text { 0.08 logMAR } \\
\text { (binocular); }\end{array}$ & $\begin{array}{l}\text { UCIVA } 0.16 \text { logMAR (monocular) } \\
\text { and } 0.13 \text { logMAR (binocular) } \\
\text { DCIVA 0.15 logMAR (monocular) } \\
\text { and } 0.1 \text { logMAR)(binocular) } \\
94.4 \% \text { satisfied or very satisfied } \\
86.8 \% \text { had no difficulty at all or } \\
\text { little difficulty performing tasks } \\
\text { that require good close-up vision }\end{array}$ & Not surgical complications \\
\hline Baikoff et a ${ }^{64}$ & Anterior plOL & Refractive & 1 year & 55 & $\begin{array}{l}0.23 \text { logMAR } \\
\text { (monocular) }\end{array}$ & Not available & $\begin{array}{l}\text { - Efficacy ratio of } 80 \% \\
\text { - Safety ratio of } 94 \%\end{array}$ & $\begin{array}{l}\text { Slight pupil ovalisation in } \\
10 \% \text { eyes }\end{array}$ \\
\hline
\end{tabular}


Table 2 Continued

\begin{tabular}{|c|c|c|c|c|c|c|c|c|}
\hline Author & IOL & Design & $\begin{array}{l}\text { Study } \\
\text { design }\end{array}$ & $\begin{array}{l}\text { Number } \\
\text { of eyes }\end{array}$ & UCNVA & BDCNVA & Additional tests & Complications \\
\hline & & & & & & & & $\begin{array}{l}\text { Mean endothelium cell loss } \\
\text { less than } 5 \% \\
410 \mathrm{~L} \text { explantations because } \\
\text { of dissatisfaction }\end{array}$ \\
\hline Alio and Mulet ${ }^{65}$ & $\begin{array}{l}\text { The AMO } \\
\text { multifocalphakic IOL } \\
\text { prototype }\end{array}$ & Refractive & 1 year & 34 & $\begin{array}{l}0.20 \text { logMAR } \\
\text { (binocular) }\end{array}$ & Not available & $\begin{array}{l}\text { UCIVA } 0.00 \text { (binocular) } \\
\text { Stereopsis near } 80.62 \mathrm{~s} \text { of arc } \\
\text { Patient satisfaction very good in } \\
88 \% \text { patients }\end{array}$ & Not surgical complications \\
\hline Cumming et $a^{166}$ & Crystalens AT-45 & Accommodative & $\begin{array}{l}1 \text { year FDA } \\
\text { clinical trial }\end{array}$ & 263 eyes & $\begin{array}{l}0.20 \log M A R \text { or } \\
\text { better in } 93.5 \% \\
\text { (binocular) }\end{array}$ & $\begin{array}{l}0.20 \log M A R \text { or } \\
\text { better in } 83.9 \% \\
\text { (binocular) }\end{array}$ & $\begin{array}{l}\text { DCIVA } 0.1 \text { in } 95 \% \text { eyes (binocular) } \\
25.8 \% \text { patients reported spectacle } \\
\text { freedom }\end{array}$ & $\begin{array}{l}\text { - Endophthalmitis } 1 \text { eye } \\
\text { 1 } 12 \text { eyes IOL dislocation } \\
\text { - } 1 \text { eyes retinal detachment } \\
\text { - } 1 \text { eye iridectomy } \\
\text { oedema } \\
\text { oedersistent corneal } \\
3 \text { eyes with iritis }\end{array}$ \\
\hline $\begin{array}{l}\text { Sanders and } \\
\text { Sanders }\end{array}$ & Tetraflex & Accommodative & $\begin{array}{l}1 \text { year FDA } \\
\text { clinical study }\end{array}$ & 255 & $0.4 \log M A R$ in $77 \%$ & $\begin{array}{l}0.4 \log M A R \text { or better } \\
\text { in } 67 \%\end{array}$ & $\begin{array}{l}-90 \% \text { could read } \geq 80 \mathrm{wpm} \text { at the } \\
0.2 \text { logMAR print size } \\
75 \% \text { patients reported never or } \\
\text { occasionally wore near glasses }\end{array}$ & Malpositioning of 5 IOLS \\
\hline Mastropasqua et al ${ }^{68}$ & 1CU Human Optics & Accommodative & 2 years & 14 & Not available & $\begin{array}{l}0.2 \log M A R \text { at } \\
6 \text { months } 0.48 \\
\text { logMAR at } 2 \text { years }\end{array}$ & $\begin{array}{l}\mathrm{AA} 1.9 \mathrm{D} \text { at } 6 \text { months and } 0.30 \mathrm{D} \text { at } \\
2 \text { years }\end{array}$ & $\begin{array}{l}\text { Anterior and posterior } \\
\text { opacification in } 100 \% \text { of cases }\end{array}$ \\
\hline Alió $(2009)^{75}$ & The Nulens & Accommodative & 1 year & $\begin{array}{l}10 \text { (Cataract and } \\
\text { atrophic macular } \\
\text { degeneration) }\end{array}$ & $\begin{array}{l}\text { Increase of } 3.8 \\
\text { Jaeger rows } \\
\text { ( } 6 \text { months) }\end{array}$ & Not available & $\begin{array}{l}\text { Cross-section measurement of } 10 \mathrm{~L} \text { of } \\
0.09 \mathrm{~mm} \text { (equivalent to } 10 \mathrm{D} \text { ) }\end{array}$ & $\begin{array}{l}1 \text { posterior synechia inducing } \\
\text { IL tilt } \\
1 \text { capsulorhexis edge capture } \\
\text { by the haptic endplate } \\
\text { inducing high myopia }\end{array}$ \\
\hline
\end{tabular}

Note: some visual acuities were converted to logMAR using the visual acuity conversion chart prepared by Jack T Holland.

AA, amplitude of accommodation; BDCNVA, best distance corrected near visual acuity; CIVA, corrected intermediate visual acuity; CS, contrast sensitivity; DCIVA, distance corrected intermediate visual acuity; LogMAR, log minimum angle of resolution; MIOL, multifocal intraocular lens; UCIVA, uncorrected intermediate visual acuity; NAVQ, Near Assessment of Vision Questionnaire; pIOL, phakic intraocular lens; UCNVA, uncorrected near visual acuity. 
axial movement of the optic resulting from action of the ciliary muscle. A hinge between the optic and haptics allows the lens to move forward as the eye focuses on near objects and backward as the eye focuses on distant objects, thereby increasing the dioptrical power of the pseudophakic eye.

It has been reported that an IOL optical shift of $1.0 \mathrm{~mm}$ can offer about 1.0 D of accommodation in a single-optic IOL and between 2.5 D and 3.0 D in an IOL with two-lens optics ${ }^{72} 73 \mathrm{In}$ addition, the amount of accommodative result depends on several factors, such as the position of the optics in the capsular bag, the posterior chamber and the refractive power of the IOL.

The Crystalens HD (Bausch \& Lomb, Rochester, New York, USA) the Tetraflex HD (Lenstec. St Petersburg, Florida, USA) and the 1CU Human Optics (Human Optics AG, Erlangen, Germany) are examples of single-optic AIOLs and have all been extensively used. ${ }^{66-68}$ Visual performance reported with these AIOLs is promising, ${ }^{66-68}$ however capsule opacification and loss of accommodative ability with time are often present.

The single-optic passive-shift IOLs are considered pseudoaccommodative because they have limited accommodative ability, as their anterior movement is insufficient to provide functionally significant amplitudes of accommodation. Hence, dual-optic devices were developed such as the Synchrony IOL (AMO, Irvine, California, USA), and the Sarfarazi IOL (Shenasa Medical, Carlsbad, California, USA). The configuration of these devices with a high positively powered mobile anterior optic, connected to a stationary negatively powered posterior optic, is designed to increase the potential accommodative amplitude. Published results of both IOLs are limited but have shown positive results in small cohorts. ${ }^{74}$ They may be relatively difficult to handle, technically.

There are some IOLs, that change their shape or curvature with accommodative effort, in different stages of development. The FluidVision lens (PowerVision, Belmont, California, USA) drives fluid of a polymer-matched refractive index from the IOL's soft haptics through channels to a fluid-driven internal activator. One-year follow-up showed that the base IOL powers were accurate and stable, VAs were good, and patients showed more than $5.00 \mathrm{D}$ of accommodation on average (American Society of Cataract and Refractive Surgery (ASCRS) 2011). The NuLens (NuLens, Herzliya Pituah, Israel), a sulcus-based accommodating IOL, is still under development although it has been implanted in 10 eyes with cataract and atrophic macular degeneration showing at 1 year, reporting this IOL may result in up to $10 \mathrm{D}$ of accommodation, ${ }^{75}$ and the Superior Accommodating IOL (Human Optics AG, Erlangen, Germany) is designed to mimic the behaviour of natural lens and it is under development.

The lens filling techniques have been under investigation for years. It consists of replacing the lens with a soft gel that would allow modifying the shape for accommodation. The Medennium SmartLens IOL (Medennium, Irvine, California, USA) is a 'smart' hydrophobic acrylic material with unique thermodynamic property. When implanted into the capsular bag, the body's temperature causes the material to transform into a gel-like polymer and take the shape of the natural lens. To the knowledge of the authors no data has been published yet. It should be noted that objective measurement of the accommodative capability of AIOLs is extremely difficult to obtain. ${ }^{76}$

\section{Lens softening}

'Softening' of the less elastic presbyopic crystalline lens is one of the newest approaches to restore accommodation. There have been some pharmaceutical attempts to act selectively on the lens and soften it, however, to the knowledge of the authors this is not a viable alternative.
The femtosecond laser seeks to restore the flexibility that has been lost by making precise incision patterns within the lens without opening the capsule.

Preclinical studies have been performed in human cadaver and animal lenses ${ }^{77-80}$ which have demonstrated safety, increased lens flexibility and no production of cataract. A feasibility study with the LENSAR (LENSAR, Orlando, Florida, USA) in 80 subjects with cataract showed that a third showed an improvement in objective accommodation measured with the Grand Seiko WR-5100 K autorefractor (Grand Seiko, Fukuyama, Japan) and over 50\% showed an improvement in subjective accommodation with the push-down method. Over $40 \%$ also showed an increase in the best distancecorrected near VA (results presented at ASCRS 2014).

Currently, there is another femtosecond laser-based therapy study for the treatment of presbyopia in Germany (The Human Eye study Cologne/Rostock). This clinical study is being conducted at two sites: University of Rostock University Eye Hospital, Rostock, Germany and Augenklinik am Neumarkt, Köln, Germany. Fifteen eyes in each site ( $\mathrm{n}=30$ eyes) have been recruited. However, to the knowledge of the authors, no data has been reported.

\section{Scleral modification}

Extraocular approaches have been developed based on Schachar's theory. ${ }^{81}$ This model states that accommodation results of an increase of zonular traction at the lens equator to increase the lens diameter, therefore, presbyopia occurs as a result of increased lens growth causing a reduction in the space between the lens and the ciliary body (circumlenticular space), such that upon contraction the zonules can no longer exert their effect on the lens due to a loss of tension. MRI studies have shown that the circumlenticular space decreases with age as a result of the inward movement of the ciliary muscle ring that occurs with advancing age and an increase of the lens thickness. ${ }^{71}$ However, goniovideography, infrared photography and MRI studies have shown that the lens decreases in diameter and surface area with accommodation. ${ }^{82}$ Despite the controversy of this theory, Schachar postulated that expanding the dimensions of the overlying scleral wall by pulling the ciliary muscle away from the equatorial edge of the lens, would reverse the process of presbyopia and increase accommodative amplitude. LaserACE (Ace Vision Group, Silver Lake, Ohio, USA) and VisAbility Implant System surgery Scleral Implants (Refocus Group, Dallas, Texas, USA) were originally developed on the basis of this theory but the actual mechanism of action is still under investigation.

\section{Laser-assisted presbyopia reversal}

Laser assisted presbyopia reversal aims to restore dynamic accommodation increasing pliability in the sclera and net forces of the ciliary muscles on the lens facilitating accommodation. The postulated mechanism of action of laser assisted presbyopia reversal is to decrease ocular rigidity. The procedure is performed using a handheld fibre-optic handpiece that delivers pulses of an erbium-YAG laser ablating a diamond matrix pattern of nine laser spots into each oblique quadrant of the sclera. These are presumed to decrease the distance between the ora serrata and the scleral spur, restore the anatomical relationships of the system and free the ciliary muscle to contract normally. The spots delivered in a diamond matrix pattern of nine laser spots into each oblique quadrant. The results so far (in 134 eyes of 67 patients after 18 months follow-up) are promising. Hipsley reported restoration of $1.25-1.75 \mathrm{D}$ of objective accommodation, which remained stable through 18 months in initial results (2011 ASCRS meeting) (table 1). 
Scleral expansion bands

Scleral expansion band surgery for the treatment for presbyopia is based on the model of accommodation theorised by Schachar. ${ }^{81}$

Scleral expansion bands have therefore been used for this purpose, but previous studies have demonstrated mixed results and have demonstrated limited success with temporary improvement in amplitude of accommodation. ${ }^{83-85}$ Most recently, Refocus group has developed The VisAbility Implant System surgery scleral implants. The technique consists of implanting four prostheses (size of a grain of rice) within elongated pockets in the sclera. The prostheses are thought to exert traction on the sclera in the region overlying the ciliary body which expands the sclera and the underlying ciliary body: thus restoring the effective working distance of the ciliary muscle and increasing the amplitude of accommodation. The actual surgical technique has evolved markedly from the initial use of manual diamond blade to the current use of disposable scleratome improving considerably the accuracy of tunnel creation. Furthermore, the original implant was a one-piece device, which was pushed into place and was difficult to thread through the tunnel. This one-single piece had a tendency to slip out of the tunnel over the long term resulting in a return or regression of patients' preoperative near vision. Nowadays, the implant is a two-piece locking implant that prevents the implanted device from slipping out. Currently, Refocus group is conducting a FDA clinical trial (table 1).

\section{CONCLUSION}

There have been significant developments in surgery for presbyopia over the last decade achieving relatively good outcomes but each modality has its own advantages and disadvantages and sometimes compromises. However, to properly compare interventions it is necessary to encourage researchers to report best distance-corrected near VA rather just UCNVA to minimise any confounding effect of myopia and astigmatism on results.

Other options for the management of presbyopia should not be forgotten, for example, it has been suggested that the use of miotics to increase depth of focus could help those suffering from presbyopia, and this would represent a type of reversible treatment. However there is little published evidence with this form of treatment, although 200 emmetropic eyes have been reported as having been treated in South America. ${ }^{86}$

In the next few years it is likely that the introduction of different IOLs will be seen, as well as the development of new pharmacological treatments and technologies to provide patients with better visual outcomes and then possibly restoration of true accommodation to the presbyopic eye will be seen.

Contributors All three authors were involved in the planning, writing and reviewing of this manuscript.

Competing interests SAN and SS have received unrestricted grants or been involved in commercial studies for Bausch and Lomb, Lenstec, Abbot Medical Optics, Oculentis GMBH, FineVision, Topcon Europe Medical BV, Refocus Group and LENSAR. SS is a consultant to Lenstec, Oculentis GMBH, Topcon Europe Medical BV, Refocus Group and LENSAR and is medical director and equity holder for CustomVis.

Provenance and peer review Not commissioned; externally peer reviewed.

\section{REFERENCES}

1 Jain S, Ou R, Azar DT. Monovision outcomes in presbyopic individuals after refractive surgery. Ophthalmology 2001;108:430-3.

2 Jain S, Arora I, Azar DT. Success of monovision in presbyopes: review of the literature and potential applications to refractive surgery. Surv Ophthalmol 1996;40:491-9.

3 Reilly $C D$, Lee $W B$, Alvarenga $L$, et al. Surgical monovision and monovision reversal in LASIK. Cornea 2006:25:136-8.

4 Levinger E, Triivizki 0, Pokroy R, et al. Monovision surgery in myopic presbyopes: visual function and satisfaction. Optom Vis Sci 2013;90:1092-7.
5 Miranda D, Krueger RR. Monovision laser in situ keratomileusis for pre-presbyopic and presbyopic patients. J Refract Surg 2004:325-8.

6 Greenbaum S. Monovision pseudophakia. J Cataract Refract Surg 2002;28:1439-43.

7 Goldberg DB. Laser in situ keratomileusis monovision. J Cataract Refract Surg 2001;27:1449-552.

8 Richdale K, Mitchell GL, Zadnik K. Comparison of multifocal and monovision soft contact lens corrections in patients with low-astigmatic presbyopia. Optom Vis Sci 2006;83:66-73.

9 Wright KW, Guemes A, Kapadia MS, et al. Binocular function and patient satisfaction after monovision induced by myopic photorefractive keratectomy. J Cataract Refract Surg 1999;25:77-82.

10 Vinciguerra P, Nizzola GM, Bailo G, et al. Excimer laser photorefractive keratectomy for presbyopia: 24-month follow-up in three eyes. J Refract Surg 1998;14:31-7.

11 Alió JL, Chaubard JJ, Caliz A, et al. Correction of presbyopia by technovision central multifocal LASIK (presbyLASIK). J Refract Surg 2006;22:453-60.

12 Luger MHA, Ewering T, Arba-Mosqueras S. One-Year experience in presbyopia correction with biaspheric multifocal central presbyopia laser in situ keratomileusis. Cornea 2013;5:644-52.

13 Baudu P, Penin F, Mosquera S. Uncorrected binocular performance after biaspheric ablation profile for presbyopic corneal treatment using AMARIS with the PresbyMAX module. Am J Ophthalmol 2013;4:636-47.

14 Reinstein DZ, Carp GI, Archer TJ, et al. LASIK for presbyopia correction in emmetropic patients using aspheric ablation profiles and a micro-monovision protocol with Carl Zeiss Meditec MEL 80 and VisuMax. J Refract Surg 2012;28:531-41.

15 Reinstein DZ, Archer TJ, Gobbe M. LASIK for myopic astigmatism and presbyopia using non-linear aspheric micro-monovision with Carl Zeiss Meditec MEL 80 platform. J Refract Surg 2011;27:23-37.

16 Reinstein DZ, Couch DG, Archer TJ. LASIK for hyperopic astigmatism and presbyopia using micro-monovision with Carl Zeiss Meditec MEL 80 platform. J Refract Surg 2009;25:37-58.

17 Uthoff D, Pölzl M, Hepper D, et al. A new method of corneal modulation with excimer laser for simultaneous correction of presbyopia and ammetropia. Graefes Arch Clin Exp Ophthalmol 2012:250:1649-61.

18 McDonald M, Durrie $D$, Asbell $P$, et al. Treatment of presbyopia with conductive keratoplasty: six-month of the 1-year United Stares FDA clinical trial. Cornea 2004;661-8

19 Menassa N, Fitting A, Auffarth GU, et al. Visual outcomes and corneal changes after intrastromal femtosecond laser correction of presbyopia. J Cataract Refract Surg 2012;5:765-73.

20 Limnopoulou AN, Bouzoukis DI, Kymionis GD, et al. Visual outcomes and safety of a refractive corneal inlay for presbyopia using femtosecond laser. J Refract Surg 2013;29:12-18

21 Garza EB, Gomez S, Chayet A, et al. One year safety and efficacy results of a hydrogel inlay to improve near vision in patients with emmetropic presbyopia. J Refract Surg 2013;29:166-72.

22 Seyeddain 0, Bachernegg A, Riha W, et al. Femtosecond laser-assisted small-aperture corneal inlay implantation for corneal compensation of presbyopia: two-year follow-up. J Cataract Refract Surg 2013;39:234-41.

23 Baily C, Kohnen T, O'Keefe M. Preloaded refractive-addition corneal inlay to compensate for presbyopia implanted using a femtosecond laser: one-year visual outcomes and safety. J Cataract Refract Surg 2014;40:1341-8.

24 Johannsdottir KR, Stelmach LB. Monovision: a review of the scientific literature. Optom Vis Sci 2001;78:646-51.

25 Asbell PA, Maloney RK, Davidorf J, et al. Conductive Keratoplasty for the correction of hyperopia. Conductive Keratoplasty Study Group. Trans Am Ophthalmol Soc 2001;99:79-84; discussion 84-7.

26 Ayoubi MG; Leccisotti A, Goodall EA, et al. Femtosecond laser in situ keratomileusis versus conductive keratoplasty to obtain monovision in patients with emmetropic presbyopia. J Cataract Refract Surg 2010;6:997-1002.

27 Lin DY, Manche EE. Two-year results of conductive keratoplasty for the correction of low to moderate hyperopia. J Cataract Refract Surg 2003:29:2339-50.

28 Moshirfar M, Anderson E, Hsu M, et al. Comparing the rate of regression after conductive keratoplasty with or without prior laser-assisted in situ keratomileusis or photorefractive keratectomy. Middle East Afr J Ophthalmol 2012;4:377-81.

29 Ruiz LA, Cepeda LM, Fuentes VC. Intrastromal correction of presbyopia using a femtosecond laser system. J Refract Surg 2009;25:847-54.

30 Holzer MP, Mannsfeld A, Ehmer A, et al. Early outcomes of INTRACOR femtosecond laser treatment for presbyopia. J Refract Surg 2009;25:855-61.

31 Holzer MP, Knorz MC, Tomalla M, et al. Intrastromal femtosecond laser presbyopia correction: 1-year results of a multicenter study. J Refract Surg 2012;28:182-8.

32 Rabsilber TM, Haigis W, Auffarth GU, et al. Intraocular lens power calculation after intrastromal femtosecond laser treatment for presbyopia: theoretic approach. J Cataract Refract Surg 2011;37:532-7.

33 Saad A, Grise-Dulac A, Gatinel D. Bilateral loss in the quality of vision associated with anterior corneal protrusion after hyperopic LASIK followed by intrastromal femtolaser-assisted incisions. J Cataract Refract Surg 2010;36:1994-8.

34 Waring IVGO, Klyce SD. Corneal inlays for the treatment of presbyopia. Int Ophthalmol Clin 2011;51:51-62. 
35 Tomita M, Kanamori T, Waring GO IV, et al. Simultaneous corneal inlay implantation and laser in situ keratomileusis for presbyopia in patients with hyperopia, myopia, or emmetropia: six-month results. J Cataract Refract Surg 2012;38:495-506.

36 Dexl AK, Seyeddain 0, Riha W, et al. One-year visual outcomes and patient satisfaction after surgical correction of presbyopia with an intracorneal inlay of a new design. J Cataract Refract Surg 2012;38:262-9.

37 Yilmaz OF, Alagoz N, Pekel G, et al. Intracorneal inlay to correct presbyopia: long-term results. J Cataract Refract Surg 2011;37:1275-81.

38 Seyeddain 0 , Riha W, Hohensinn $M$, et al. Refractive surgical correction of presbyopia with AcuFocus small aperture corenal inlay: two year follow-up. J Refract Surg 2010;26:707-15.

39 Keates RH, Pearce JL, Schneider RT. Clinical results of the multifocal lens. J Cataract Refract Surg 1987;13:557-60.

40 Knorz MC. Results of a European multicenter study of the True Vista bifocal intraocular lens. J Cataract Refract Surg 1993;19:626-34.

41 Slagsvold JE. $3 \mathrm{M}$ diffractive multifocal intraocular lens: eight-year follow-up. J Cataract Refract Surg 2000;26:402-7.

42 Chiam PJ, Chan JH, Haider SI, et al. Functional vision with bilateral ReZoom and ReSTOR intraocular lenses 6 months after cataract surgery. I Cataract Refract Surg 2007;33:2057-61.

43 Santhiago MR, Wilson SE, Netto MV, et al. Visual performance of an apodized diffractive multifocal intraocular lens with +3.00 -d addition: 1-year follow-up. J Refract Surg 2011;27:899-906.

44 Woodward MA, Randleman JB, Stulting RD. Dissatisfaction after multifocal intraocular lens implantation. J Cataract Refract Surg. 2009;35:992-7.

45 Leccisotti A. Secondary procedures after presbyopic lens exchange. J Cataract Refract Surg 2004;30:1461-5.

46 Alió JL, Plaza-Puche AB, Piñero DP, et al. Quality of life evaluation after implantation of 2 multifocal intraocular lens models and monofocal model. J Cataract Refract Surg 2011,37:638-48.

47 Davison JA, Simpson MJ. History and development of the apodized diffractive intraocular lens. J Cataract Refract Surg 2006;32:849-58.

48 Forte R. Ursoleo P. The ReZoom multifocal intraocular lens: 2-year follow-up. European J Ophthalmol 2009:19:380-3.

49 Mesci C, Erbil HH, Olgun A, et al. Visual performances with monofocal, accommodating, and multifocal intraocular lenses in patients with unilateral cataract. Am J Ophthalmol 2010;150:609-18.

50 Cezón J, Bautista M-J. Visual outcomes after implantation of a refractive multifocal intraocular lens with a +3.00 D addition. J Cataract Refract Surg 2010;36:1508-16.

51 Cillino S, Casuccio A, Di Pace F, et al. One-year outcomes with new-generation multifocal intraocular lenses. Ophthalmology 2008;115:1508-16.

52 de Vries NE, Webers CA, Touwslagers WR, et al. Dissatisfaction after implantation of multifocal intraocular lenses. J Cataract Refract Surg 2011;37:859-65.

53 Gooi P, Ahmed IK. Review of presbyopic IOLs: multifocal and accommodating IOLS. Int Ophthalmol Clin 2012;52:41-50.

54 Kohnen T, Allen D, Boureau C, et al. European multicenter study of the AcrySof ReSTOR apodized diffractive intraocular lens. Ophthalmology 2006;113:578-84.

55 Packer M, Chu YR, Waltz KL, et al. Evaluation of the aspheric Tecnis multifocal intraocular lens: one-year results from the first cohort of the food and drug administration clinical trial. Am J Ophthalmol 2010;149:577-84.

56 Voskresenskaya A, Pozdeyeva N, Pashtaev N, et al. Initial results of trifocal diffractive IOL implantation. Graefes Arch Clin Exp Ophthalmol 2010;248:1299-306.

57 Mojzis P, Pena-Garcia P, Liehneova I, et al. Outcomes of a new diffractive trifocal intraocular lens. J Cataract Refract Sur 2014;40:60-9.

58 Sheppard A, Shah S, Bhatt U, et al. Visual outcomes and subjective experience after bilateral implantation of a new diffractive multifocal intraocular lens. J Cataract Refract Surg 2013;39:343-9.

59 Mc Alinden C, Moore JE. Multifocal intraocular lens with a surface-embedded near section: short-term clinical outcomes. J Catarct Refract Surg 2011;37:441-5.

60 Alió JL, Piñero DP, Plaza-Puche $A B$, et al. Visual outcomes and optical performance of a monofocal intraocular lens and a new-generation multifocal intraocular lens. J Cataract Refract Surg 2011;37:241-50.
61 Ramón ML, Piñero DP, Pérez-Cambrodí RJ. Correlation of visual performance with quality of life and intraocular aberrometric profile in patients implanted with rotationally asymmetric multifocal IOLs. J Refract Surg 28 2012;28:93-9.

62 Berrow EJ, Wolffsohn J, Bilkhu PS, et al. Visual performance of a new bi-aspheric, segmented, asymmetric multifocal intraocular lens. J Refract Surg 2014;30:584-8

63 Venter JA, Barclay D, Pelouskova $M$, et al. Initial Experience with a new refractive rotationally asymmetric multifocal intraocular lens. J Refracr Surg 2014;30:770-6.

64 Baikoff $G$, Matach $G$, Fontaine $A$, et al. Correction of presbyopia with refractive multifocal phakic intraocular lenses. J Cataract Refract Surg 2004;30:1454-60.

65 Alio JL, Mulet ME. Presbyopia correction with an anterior chamber phakic multifocal intraocular lens. Ophthalmology 2005;112:1368-74.

66 Cumming JS, Colvard DM, Dell SJ, et al. Clinical evaluation of the Crystalens AT-45 accommodating intraocular lens- Results of the US Food and Drug Administration clinical trial. J Cataract Refract Surg 2006;32:812-25.

67 Sanders DR, Sanders ML. Tetraflex Presbyopc IOL study Group. US FDA clinical trial of the Tetraflex potentially accommodating IOL: comparison to concurrent age-matched monofocal controls. J Refract Surg 2010;26:723-30.

68 Mastropasqua L, Toto L, Falconio G, et al. Longterm results of 1 CUß accommodative intraocular lens implantation: 2-year follow-up study. Acta Ophthalmologica Scandinavica 2007;85:409-14.

69 Baikoff G. Refractive phakic IOLs then and now. J Cataract Refract Surg Today 2004;72-4.

70 Bacskulin A, Gast R, Bergmann U, et al. Ultrasound biomicroscopy imaging of accommodative configuration changes in the presbyopic ciliary body. Ophthalmologue 1996;93:199-203.

71 Strenk SA, Semmlow JL, Strenk LM, et al. Age related changes in human ciliary muscle and lens: a magnetic resonance imaging study. Invest Ophthalmol Vis Sci 1999:40:1162-9.

72 Langenbucher A, Huber S, Nguyen NX, et al. Measurement of accommodation after implantation of an accommodating posterior chamber intraocular lens. J Cataract Refract Surg 2003;29:677-85.

73 McLeod SD. Optical principles, biomechanics, and initial clinical performance of a dual-optic accommodating intraocular lens (an American Ophthalmological Society thesis). Trans Am Ophthalmol Soc 2006;104:437-52, 20.

74 Ossma IL, Galvis A, Vargas LG, et al. Synchrony dual-optic accommodating intraocular lens-Part 2: pilot clinical evaluation. J Cataract Refract Surg 2007;3347-52

75 Alió JL, Ben-nun J, Rodriguez-Prats JL, et al. Visual and accommodating outcomes 1 year after implantation of an accommodating intraocular lens based on a new concept. J Cataract Refract Surg 2009;35:1671-8.

76 Pallikaris IG, Kontadakis GA, Portaliou DM. Real and pseudoaccommodation in accommodative lenses. J Ophthalmol 2011:2011:284961.

77 Krueger RR, Sun XK. Novel approaches to correction of presbyopia with laser modification of the crystalline lens. J Refract Surg 1998:14:136-9.

78 Ackerman R, Kunert KS, Kammel R, et al. Femtosecond laser treatment of the crystalline lens: a 1-year study of possible cataractogenesis in minipigs. Graefes Arch Clin Exp Ophthalmol 2011;249:1567-73.

79 Schumacher S, Oberheide U, Fromm M, et al. Femtosecond laser induced flexibility change of human donor lenses. Vision Res 2009;49:1853-9.

80 Blum M, Kunert K, Nolte $\mathrm{S}$, et al. Presbyopia treatment using a femtosecond laser. Ophthalmologe 2006;103:1014-19.

81 Schachar RA. Pathophysiology of accommodation and presbyopia: understanding the clinical implications. J Fla Med Assoc 1994;81:268-71.

82 Glasser A, Kaufman PL. The mechanism of accommodation in primates. Ophthalmology 1999;106:863-72.

83 Qazi MA, Pepose JS, Shuster JJ. Implantation of scleral expansion band segments for the treatment of presbyopia. Am J Ophthalmol 2002;134:808-15.

84 Malecaze FJ, Gazagne CS, Tarroux MC, et al. Scleral expansion bands for presbyopia. Ophthalmology 2001;108:2165-71.

85 Kleinmann Guy, Kim Hee Joon, Yee Richard W. Scleral expansion procedure for the correction of presbyopia. Int Ophthalmol Clin 2006;46:1-12.

86 Benozzi J, Benozzi G, Orman B. Presbyopia: a new potential pharmacological treatment. Med Hypothesis Discov Innov Ophthalmol 2012;1:3-5. 